\title{
A Discussion on the Conformity between the Cognitive Characteristics of Brand Connotation and Brand Extension Mode
}

\author{
Yuanbing Liu ${ }^{1}$ and Wenbin Liu ${ }^{2, a^{*}}$ \\ ${ }^{1}$ Hunan University of Arts and Science, Hunan,415000, China \\ ${ }^{2}$ Wuhan Technology and Business University, Wuhan,430065, China \\ a812926096@qq.com \\ * The corresponding author
}

Keywords: Brand extension; Brand connotation; Cognitive characteristics

\begin{abstract}
Brand extension must take into account the cognitive dimension of the brand connotation of the parent brand. The brand extension mode can effectively promote the brand extension only when it fits with the product information attribute, the specific function and the technical attribute, and the symbolic attribute.
\end{abstract}

\section{Introduction}

Brand extension refers to an enterprise using its brand name to expand its product or launch a new product category with the help of the consumer influence of an existing mature brand. Because brand extension strategy can greatly reduce the risk of new products to enter the market, lower costs achieve greater market returns. Therefore, brand extension has become a brand strategy widely used by many companies in other industries. Research shows that the proportion of new products using brand extension is as high as $95 \%$ in the 1980s. With the development of brand extension practice, since published "Brand Authorization extension, the new product is suitable for the old brand" in 1979, Edward put forward the theoretical question of brand extension for the first time, the research on brand extension has become a hot spot in the field of brand research. Influential research results include Boush, Allen and Bragg, the effect and value of brand extension is analyzed from different angles. This research has made the detailed elaboration to the various influence factors of brand extension, the influence of brand extension to the original brand rights and interests and the change of brand positioning, etc.

The current research on brand extension focuses on the following aspects. The first is the study of consumers evaluation of brand extension. The second is the research on the influencing factors of brand extension. The third is the empirical research on the conditions and ways of introducing brand extension, including the direction and order of brand extension. The Fourth is the research on the process of brand extension of consumer evaluation.

\section{Analysis of Cognitive Connotation Characteristics of Brand}

Although brand connotation is based on the functional attributes of the product itself, Contemporary brand theory is more inclined to evaluate brand connotation from the perspective of consumers undefined perception and cognition, and believes that brand connotation is the internal and external form of expression, can bring consumers differentiated benefits. This difference allows consumers to distinguish one brand from another brand or general goods. The cognitive connotation dimension of brand is divided into three dimensions: product information attribute dimension, functional attribute dimension and symbolic attribute dimension in the paper. The cognitive dimension of all these brands has evolved. Along with the consumer participants consumption experience and consumer information interaction, consumers have a certain degree of understanding of the properties of the goods purchased, and continue to strengthen and expand the consumption experience in the future. Thus consumers gradually associate their specific cognition of the brand 
with the specific brand, which makes the brand begin to have the cognitive connotation characteristics.

Since brand extension is to make use of consumers' cognition of the connotative characteristics of the parent brand to influence consumers' cognition of the extended products, only from the perspective of consumers' cognition and consumers' association with the parent brand, they can grasp the brand connotation characteristics to ensure the success of brand extension strategy. The combination of the brand connotation characteristic dimension of the mother brand and the extended brand directly affects the consumers' decision to extend the brand product. Based on this judgment, successful brand extension requires the determination of brand connotation, so as to establish a solid foundation for the correct implementation of brand extension strategy. As far as the connotation characteristic level of brand is concerned, three levels of brand connotation characteristic dimension is summarized in this paper .

\section{The Attribute Dimension of Product Information in the Characteristic Dimension of Brand Connotation}

The first dimension of product brand cognitive feature dimension is the attribute dimension of product information, including the basic use value, scale and overall management ability of the product. This is the basic brand connotation dimension. For consumers, this level of product brand connotation characteristic dimension has played a basic material attribute to the commodity, including product trademark, trademark advertising language, product attribute feature, product scope, purpose, manufacturer scale and ability, countries of origin. A brand is just a symbol of a commodity and does not add value to the brand. From the consumer point of view, the main function of the brand is the function of information transmission and information screening. The products with the characteristic dimension of the brand connotation can save the transaction cost for the consumers and help the consumers to position themselves quickly to satisfy their basic function products. Most brands, especially corporate brand connotation, mostly belong to this dimension.

The Specific Function and Technical Attribute Dimension in the Characteristic Dimension of Brand Connotation. The second level of the product brand connotation characteristic dimension is the brand function and technology attribute dimension, compared with the first level product information attribute dimension. The dimension of this level shows that the product has more superior or differential physical properties or technical features than the same product, which makes the product brand have some additional value different from the other products of the same kind. The consumers cognition of the products with the characteristic dimension of the brand connotation is mainly based on this particular function and technical attribute as the brand cognitive association domain. For example, Yunnan Baiyao and Rebecca( two brands), the former because Yunnan Baiyao ( this product ) has significantly better than the functional characteristics of similar products in promoting blood stasis, detumescence and pain, expelling wind and dehumidification . Consumers will easily associate Yunnan Baiyao brand with promoting blood stasis, detumescence and pain, wind-removing dampness. The latter(Rebecca) is due to leading wigs manufacturing process in the world. Consumers will associate the Rebecca brand with a particular technology called wig manufacturing. Generally speaking, the goods with this level of brand connotation will have more market tension than the first level of brand connotation.

The Symbolic Attribute Dimension in the Characteristic Dimension of Brand Connotation. The third dimension of the cognitive dimension of product brand connotation is the symbolic association dimension of brand. This brand connotation characteristic dimension indicates that the consumer cognitive connection object is the spiritual value, and the effect of the product is not the first concern of the consumer. The dimension of brand connotation characteristic of this level develops with the development of consumer individualized consumption idea and the trend of individualized consumption. Consumers of individualized consumption take more account of personal satisfaction, spiritual pleasure, comfort and superiority when consuming goods. Consumers choose and purchase goods or services on the basis of individual psychological desire. Consumers should reflect their own value in the process and object of consumption. Consumer 
consumption is to obtain psychological satisfaction and sense of pleasure. As far as the symbolic content of the commodity is concerned, it can be further divided into three categories: personal identification symbol, social identification symbol, status identification symbol and emotional identification symbol. The formation of this level of brand connotation features is the formation of various consumer participants through product design, advertising, television, magazines and other media significance injection and interaction.

\section{Discussion on the Connotation Characteristic Dimension and Extension Mode of Brand}

The classification criteria for specific models of brand extension fall into the following three categories. On the basis of this, the consonance between the connotation characteristic dimension of brand and the mode of brand extension is analyzed.

The First Category is Divided into Mother and Child Brand Extension and Single Brand Extension. Brand extension must be considered from the consumers existing cognition of the connotative characteristics of the parent brand. The key is whether the consumer can connect the extended product with the connotation of the parent brand. According to the brand cognition theory, consumers cognition and attitude to the parent brand will have a direct impact on the cognition and attitude of the extended product. And consumers cognition of brand connotation dimension will limit the brand extension model. This is because the consumers cognition of the brand connotation characteristic dimension reflects the unique cognition of the consumers connection to the parent brand. If the enterprise can effectively connect the connotation characteristic dimension of the brand cognition to the extended product, consumers will have emotional resonance, accept the new product easily, and the brand extension will be easy to obtain success. On the other hand, the brand extension of new products does not accord with the consumer cognition of the original brand connotation, or obscures the unique brand connotation characteristics of the original brand. It will give consumers a vague sense of brand awareness. Then it is difficult to obtain the positive attitude of consumers to the original brand, and the purpose of brand extension can not be achieved by using the original brand equity effectively.

The Second Category is Divided into Upward Extension, Downward Extension and Twoway Extension. Considering the consistency between the cognitive characteristics of brand connotation and the mode of brand extension, the brand with the first level of brand connotation is not suitable for cross-industry brand extension. This is because the brand is simple at this level of brand connotation features. Because of such factors as size and long operating time, consumers have a certain understanding of the brand. This cognition only plays the role of general information transmission or information screening to save transaction costs, and the brand itself does not provide special added value. Consumers don't associate a brand with a particular symbol or with a particular function and technology. If the range of the product extends beyond the original industry, it will affect the bond strength between the parent brand product and the extended product because of the lack of cross industry brand connection points. Consumers association with products will take into account whether the connotation of the original product brand is linked to the extended commodity. It is only when two products are considered relevant by consumers, including specific functions or technology or symbolism, that they can contribute to the manufacture and production of extension products, and brand extension can be recognized, and consumers will have a sense of identity with the extended products. Therefore, this level of brand extension is suitable for the same industry upward, downward or two-way extension strategy, and the best extension mode is the mother-child brand extension model, because it can make full use of the information function of the original brand.

The Third Category is Divided into The same Industry Brand Extension and Crossindustry Brand Extension. For the parent brand whose brand connotation is the dimension of specific function or technical attribute, the product knowledge related to the parent brand product owned by consumers is more specific and detailed than the brand product with only product information attribute brand connotation level. Consumers are more dependent on existing consumer knowledge and experience. The brand can bring the brand guarantee effect and product guarantee 
effect to the consumer. When the brand extension has this level brand connotation characteristic dimension, as long as the extended product can be connected with the specific function or technical attribute of the original brand, The positive attitude and cognition of the parent brand can be transferred smoothly to the cognition of the extended product. Therefore, as far as the fit mode of brand extension is concerned, for product brands with specific functional and technical brand connotations, it includes cross-industry brand extension mode and intra-industry development. Downwards or bidirectional brand extension models are likely to fit. However, it is worth paying attention to the limitation of the brand which has the characteristic of too strong specific function and technical attribute when adopting the mother-child brand extension mode. Because brands with this level of connotation are too functional and technical, there is little room for the mother-child brand to extend the product line, sometimes diluting the brand connotation. Most of the brands with symbolic attributes are associated with identity, status, emotion and so on. They are common in luxury and luxury goods. What consumers need is the personal identification effect, the social identification effect and the status guarantee effect brought by the brand. The use effect of the brand product is no longer the main factor to be considered by consumers. Consumers recognize products with this level of brand connotation through trademark names, logos, designs, styles, services, even price preferences or brand symbolic associations.

As long as the consumer establishes the brand symbolic connection cognition, it will arouse the consumer to buy the desire to produce. Inspiring the consumer to buy is the spiritual value of the product. When choosing the brand extension mode, we should try our best to adopt the vertical brand extension mode in the industry, but we should pay attention to two points. First, the extended span should not be too large. If the extended span is too large, it will inevitably affect the consumers of the original brand, because this kind of consumer group buys the product in order to enjoy the personal, social and status guarantee utility brought by the brand, and deviates from this principle. It will dilute the brand connotation of the original product and lose the target market. Second, the strategy of extending upward within the industry should be adopted as far as possible. Because the brand extension in the upward direction can effectively enhance the symbolic value of the brand and improve the image of the original brand. The downward extension will seriously affect the value of brand equity.

\section{References}

[1] Junwu Chai, Guangzhi Zhao, We He. The influence of the interpretation level on brand association and brand extension assessment [J]. Journal of Psychiatry, 2011(02).

[2] Guohui Sun, Huiling Han. Research on the forming Mechanism of Brand symbolism[J]. Journal of Central University of Finance and Economics, 2014(09)

[3] Yanfeng $\mathrm{Xu}$,Xiaokang Zhao. The Influence Mechanism of Perceptual Matching and Engagement on Brand Extension Evaluation.[J]. Journal of Beijing Technology and Business University (Social Science Edition), 2014(02).

[4] Yu D, Peng L. When does Inferring Reputation Probability Countervail Temptation in Cooperative Behaviors for the Prisoners' Dilemma Game? [J]. Chaos, Solitons \& Fractals, 2015, 78: 238-244. 